\title{
A Survey on the Pteridophyte Flora of the 18 Selected Sacred Groves in Chalavara Grama Panchayath, Palakkad District, Kerala
}

\author{
Praveen Kumar K and Udayan P.S.
}

\author{
P.G and Research Department of Botany, Sree Krishna College, Guruvayur, Ariyannur (P.O), Thrissur District, Kerala, India
} praveenkumarkvk1992@gmail.com

\begin{abstract}
An exploratory survey conducted on Pteridophytic flora in the 18 selected sacred groves of Chalavara Grama panchayath, Ottapalamtaluk, Palakkad district, Kerala lead to the collection of 26 species of pteridophytes coming under 20 genera and 14 families. Among them, 02 families belongs to class Lycopsida, 01 family belongs to class Psilotopsida and remaining belongs to class Polypodiopsida. Out of 26 species 21 species are terrestrial, 3 species are epiphytes and 2 species are aquatic.
\end{abstract}

Keywords-Diversity, Sacred groves, Chalavara, Palakkad.

\section{INTRODUCTION}

Sacred grooves are the conserved forest patches or protected areas. The sacred groves in Kerala are tightly bonded with religional backgrounds. The (Its) conservation is mainly based on cultural, aesthetical and religional aspects, In different areas this sacred places are devoted or dedicated for different Gods i.e. serpentine Gods, Nagadevatha, Nagayakshi .etc. Human activities are highly prohibited in these areas. Touching plants (and animals associated with them ) in these sacred groves and gardens was forbidden to all except the temple priest, and his too is restricted to offerings to the Presiding temple Deity and curing the ailments of local people (the temple priest was in variably the village doctor). The study area includes one of the famous sacred groove and serpentine temple, Pathirakkunnathu mana. The present technocratic and scientifically oriented society mistakenly considers that religion is not interested in protecting and managing biodiversity. The truth, however, is that religious values very often help to protect biodiversity. The practice of protection of patches of forests with temples in their vicinity has long been in vogue in India and a few other parts of the World. In some instances, forest patches or gardens with local floristic elements (often called Nandavanas) have been specially created near established temples are declared sacred to ensure their protection and conservation. Such sacred groves and gardens dedicated to the worship of the Presiding Deity of each temple are mentioned in ancient Greek, Latin American and Indian literary works as well as in epigraphically records and copper plates of these countries. Data also come from folk traditions, history and traditional knowledge passed on through several generations.

Sacred grooves are biologically important places having maximum species diversity and richness. Besides this sacred grooves are the significant ecosystem in the terrestrial biome. Angiosperms are the abundant vegetation in here, mainly trees and climbers, herbaceous forms are relatively limited in number, however some pteridophytes, certain members of Asteraceae, Piperaceae, are substituting this purpose. In some areas large trees are dominant whereas in some other areas climbers are majority. The soil in these places is nutrient rich and water filled, rocky regions contain members of Riccia, Funaria, Marsilia.etc.

This study includes a Taxonomical approaches to the Pteridophytic flora in sacred groves. Pteridophytes are flourished in sacred groves. It's watery or moisture nature is suitable for pteridophytes, some are epiphytic forms on tree members some others are herbs and climber like Lygodium. Drastic variations among species are common. Sacred groves are the original replica of natural forests of the locality. It may comprise of a single tree to a very large forest tract. It is considered as sacred because of the deity associated with the grove. Hence it may call as temple forests, which are one of the oldest forms of conserving natural forests. This unique community linked forest conservation concept is followed in many tribal and agrarian regions of the world.

Pteridophytes constitute an important part of the world flora. Pteridophytes are of immense economic importance and there is a great need for their exploitation 
towards the economic utility in our day to day life. Ferns show various economic values towards food and fodder, biological indicators, bio fertilizers, insect repellants, medicine and folk remedies. But still the question whether the full potential of these intriguous plants have been ever exploited by the humans remains. Quite a large number of them cultivated as ornamentals either indoors in the houses or outdoors in the botanical gardens due to their delicate beauty and grace. The hybrids of different species are now elegant, expensive, representative members in horticulture. Another chief economic importance of the pteridophytes is that their fossil remains contributed to the coal depositions of the world.Thus we can see that ferns are a group of unique plants and they have immersed potential to be studied and utilized in different areas of economic and academic interest. The current study is a humble attempt to enumerate and identify the pteridophytic flora of sacred grooves of the Chalavaragramapanchayath, Ottapalam, Palakkad, Kerala.

\section{MATERIALS AND METHODS}

The present study was carried out to assess and analyse the pteridophytes flora of sacred groves of Chalavara Grama Panchayath, Palakkad district, Kerala. The Materials for this study were collected from area of study during January 2016 to July 2016. Field trips to various habitats were made during the study period for plant collection. During the collection, field observations such as habit, habitat, and date of collection were noted in the field itself and the diagnostic features of all the specimens were studied and field notes were made on fresh plant materials.

From the available habitats, sporophytic habits were collected along with rhizome as far as possible. Plants collected were carefully handled and covered with moistened newspapers without causing any harm to the tender parts. In case of large plants, exact size was noted down and then the fronds were cut in to pieces, which were then used to prepare the herbarium. More than one specimens of each plant were collected for further identification, observation and herbarium preparation. About 36 species have been collected from the area. The colour photographs from the natural habitat were taken during the collection using digital camera (Sony-Cyber shot W810). Plants with sporophylls were collected as far as possible.

Fresh materials were used for the study in the laboratory. Morphological characters of the sporophytic plant body were studied. External characters of the spores and sporangia were also noted in selected plants. Enumerations of collected specimens were done by observing a morphological feature under stereozoom microscope (LABOMED D500) Identification of the specimens was done by using the Pteridophytes flora of the Western Ghats- South India (Manickam and Irudayaraj 1992). All the identified species of ferns have been classified and arranged according to Smith et al., 2006 with some modification as per Fraser-Jenkins (2009), regarding their correct nomenclature and classification of fern allies.

The collected specimens were properly processes as herbarium specimens, carefully spread on the newspaper. The large sized plants were bent into $\mathrm{V}$ or $\mathrm{W}$ shapes and these specimens were bound tightly in plant press. The newspaper sheets were changed regularly until the specimens got dried completely. The dried specimens were mounted on herbarium sheets by using synthetic gum. The herbarium sheets were neatly labeled by using the details from the field note book. All the herbaria prepared for the present study were deposited in Sree Krishna College herbarium.

\section{RESULTS AND DISCUSSION}

Fern and fern allies are almost neglected group of plants distributed all over the world. They are live in a wide variety of habitats from remote mountain elevations to dry desert rock faces, to bodies of water or in open fields. Some ferns are serious weed species. The present study revealed the occurrence of 26 species of pteridophytes in the sacred groves of Chalavara Grama Panchayath. This belongs to 20 genera under 14 families. Based on their habitats various members of fern and fern allies are classified in to following categories, out of 26 species 21 species are $(81 \%)$ terrestrial, 2 species are $(8 \%)$ aquatic and 3 species are (11\%) epiphytes. (Table 1).

The present study identified 2 ecologically significant species such as Salvinia molesta (African payal) and Marsilea minuta as their wide distribution as weeds in ponds and paddy fields. Salvinia molesta, a free floating aquatic fern, is one of the World's worst aquatic weeds (Madhusoodanan, 1989). As the plant die, organic debris accumulates at the bottom of the water column and can threaten fisheries by creating a shallow - water environment less suited to fish breeding (Sculthrope, 1985). Pyrrosia heterophylla growing as epiphyte in less polluted area, their absence indicates pollution (this species only obtained from). A detailed survey on the fern flora of a particular region becomes significant only if it can do any good to the conservation practices of these endangered plants. Lack of knowledge or rather interest among Botanists is one of the main reasons for negligence faced by ferns. So familiarizing ferns and including them with almost equal importance to 
the Angiosperms is a way out from the threatened status of these plants. The economic and medicinal use of them should be explored more and by this ferns can attain a significant position I plant kingdom. Prior to all this all the manipulations and misidentifications of these plants should be rectified for adopting better conservation strategies and for exploring the wide applications of these plants to be used for the betterment of mankind and life on earth as a whole.

Table.1: List of Pteridophytes collected from 18 sacred groves

\begin{tabular}{|c|c|c|c|c|}
\hline Class & Family & Genus & Species & Habitat \\
\hline $\begin{array}{l}\text { I. } \\
\text { Lycopsida }\end{array}$ & $\begin{array}{l}\text { 1. Lycopodiaceae } \\
2 . \\
\text { Selaginellaceae }\end{array}$ & $\begin{array}{l}\text { 1. Lycopodiella } \\
\text { Selaginella }\end{array}$ & $\begin{array}{l}\text { 1. Lycopodiella cernua L. } \\
\text { 2. S. delicatula (Desv.) Alston. } \\
\text { 3. S. wildenovi (Desv. ex Poir.) Baker. } \\
\text { 4. S. ciliaris (Retz.) Spring }\end{array}$ & $\begin{array}{l}\mathrm{T} \\
\mathrm{T} \\
\mathrm{T} \\
\mathrm{T}\end{array}$ \\
\hline $\begin{array}{l}\text { II. } \\
\text { Psilotopsid } \\
\text { a }\end{array}$ & $\begin{array}{l}\text { 3. } \\
\text { Ophioglossaceae } \\
\text { 4. Gleicheniaceae }\end{array}$ & $\begin{array}{l}\text { 2. Ophioglossum } \\
\text { 3. Dicranopteris }\end{array}$ & $\begin{array}{l}\text { 5. Ophioglossum reticulatum L. } \\
\text { 6. Dicranopteris linearis (Burm.f.) Undrew. }\end{array}$ & $\begin{array}{l}\mathrm{T} \\
\mathrm{T}\end{array}$ \\
\hline $\begin{array}{l}\text { III. } \\
\text { Polypodiop } \\
\text { sida }\end{array}$ & $\begin{array}{l}\text { 5. Lygodiaceae } \\
\text { 6. Marsileaceae. } \\
\text { 7. Salviniaceae } \\
\text { 8. Lindsaceae } \\
\text { 9. Pteridaceae } \\
\text { 10. } \\
\text { Thelypteridaceae } \\
\text { 11.Woodsiaceae } \\
\text { 12.Blechnaceae } \\
\text { 13.Lomariopsida } \\
\text { ceae } \\
\text { 14.Polypodiaceae }\end{array}$ & $\begin{array}{l}\text { 4. Lygodium } \\
\text { 5. Marsilea } \\
\text { 6. Salvinia } \\
\text { 7. Lindsaea } \\
\text { 8. Pteris } \\
\text { 9. Adiantum } \\
\text { 10. Cheilanthes } \\
\text { 11. } \\
\text { Parahemionitis } \\
\text { 12. } \\
\text { Pityrogramma } \\
\text { 13. Christella } \\
\text { 14. } \\
\text { Macrothelypteris } \\
\text { 15. Athyrium } \\
\text { 16. Stenochlaena } \\
\text { 17. Nephrolepis } \\
\text { 18. Drynaria } \\
\text { 19. Pyrrosia }\end{array}$ & $\begin{array}{l}\text { 7. Lygodium flexuosum (L.)Sw. } \\
\text { 8. Marsilea minuta } \mathrm{L} . \\
\text { 9. Salvinia molesta Mitch. } \\
\text { 10. Lindsaea ensifolia Sw. } \\
\text { 11. Pteris vittata } \mathrm{L} . \\
\text { 12. P. pellucida } \text { Presl. } \\
\text { 13. P. confusa T.G. Walker. } \\
\text { 14. Adiantum philippense L. } \\
\text { 15. A. latifolium Lam. } \\
\text { 16. Cheilanthes tenuifolia (Burm. f.) Sw. } \\
\text { 17. Parahemionitis cordata (Roxb. ex Hook. } \\
\text { and Grev.) } \\
\text { Fraser-Jenk. } \\
\text { 18. Pityrogramma calomelanos (L.) Link } \\
\text { 19. Christella dentata (Forssk.) Brownsey and } \\
\text { Jermy. } \\
\text { 20. Macrothelypteris torresiana (Gaudich.) } \\
\text { Ching } \\
\text { 21. Athyrium hohenackeranum (Kunze) T. } \\
\text { Moore. } \\
\text { 22. Stenochlaena palustris (Burm.) Bedd. } \\
\text { 23. Nephrolepis cordifolia (L.) Presl. } \\
\text { 24. Drynaria quercifolia (L.) J. Smith. } \\
\text { 25. Pyrrosia lanceolata Farwell } \\
\text { 26. P. heterophylla (L.) M. G. Price }\end{array}$ & $\begin{array}{c}\mathrm{T} \\
\mathrm{A} \\
\mathrm{A} \\
\mathrm{T} \\
\mathrm{T} \\
\mathrm{T} \\
\mathrm{T} \\
\mathrm{T} \\
\mathrm{T} \\
\mathrm{T} \\
\mathrm{T} \\
\mathrm{T} \\
\mathrm{T} \\
\mathrm{T} \\
\mathrm{T} \\
\mathrm{T} \\
\mathrm{T} \\
\mathrm{T} \\
\mathrm{E} \\
\mathrm{E} \\
\mathrm{E}\end{array}$ \\
\hline
\end{tabular}

T: Terrestrial; A: Aquatic E: Epiphyte

\section{CONCLUSION}

A detailed survey on the fern flora of a particular region becomes significant only if it can do any good to the conservation practices of these endangered plants. Lack of knowledge or rather interest among Botanists is one of the main reasons for negligence faced by ferns. So familiarizing ferns and including them with almost equal importance to the Angiosperms is a way out from the threatened status of these plants.The present study identified 2 ecologically significant species such as Salvinia molesta (African payal) and Marsilea minuta as their wide distribution as weeds in ponds and paddy fields. Sacred groves as well as 
pteridophytes are needs an immediate attention in the modern sense.

\section{ACKNOWLEDGEMENTS}

The first author expressing his sincere gratitude to Dr. G. Jayakishnan, M.Sc., M.Phil., Ph.D. Head of the Department of Botany Sree Krishna College for providing necessary facilities, without which this work would not have materialized. I am grateful to Chalavara Grama Panchayath, Palakkad District Panchayath and The owners of the studied sacred groves.

\section{REFERENCES}

[1] Fraser-Jenkins, C.R. 1997. New Species Syndrome in India Pteridology and the Ferns of Nepal. International Book Distribution. Dehra Dun.

[2] Fraser-Jenkins, C.R. 2008.Taxonomic Revisions of Three Hundred Indian Subcontinental Pteridophytes with a Revised Census- List. Bishen Singh Mahendra Pal Singh. Dehra Dun: 685.

[3] Fraser-Jenkins, C.R. 2009. A Brief Comparison of Modern Pteridophyte Classifications (Families and genera in India) Indian Fern Jour. 26: 107-126.

[4] Madhusoodanan, P.V. and Nampy, S.1998. Biodiversity of the Ferns and Fern allies of Kerala. Indian Jour. Econ.Tax. Bot. 22: 183-189.

[5] Madhusoodanan, P.V., Sijimoli, P.S. and Rajesh, K.P. 2001. Pteridology in South India- retrospection. Indian Fern Jour. 18: 18-34.

[6] Madhusoodanan, P.V., Sreerenjini, V.K., Smitha, A.B. and Prakashkumar, R. 2014. Invasion of Salvinia molesta D.S. Mitchell. (African Payal) in Kerala and its Management Indian Fern Jour. 31: 156- 166.

[7] Manickam, V.S. and Irudayaraj, V.1992. Pteridophyte Flora of the Western Ghats-South India. B. I. Publications, New Delhi. 3:48-49.

[8] Sculthorpe, C. D. 1985. The biology of aquatic vascular plants. Edward Arnold, London. pp. 124-151. 